\title{
Species diversity of natural rhizobia populations of the Russian Far East
}

Yakimenko M.V., Begun S.A., Sorokina A.I.

FSBSI All-Russian Scientific Research Institute of Soybean, Blagoveshchensk, Amur region

$$
\text { E-mail: mariy-y@yandex.ru }
$$

Key message. The specificity of the soils of the Far East is the presence of aboriginal soybean nodule bacteria in them. A detailed study of the morphological and cultural, physiological and economically useful properties of these microorganisms made it possible to identify the most valuable strains of B. japonicum, S. fredii, B. elkanii from the Far Eastern natural populations for their preservation in the collection.

Keywords: soybean, legumes, rhizobia, species, strains

The Far East region as a region engaged in soybean cultivation is the only one in Russia where natural populations of soybean nodule bacteria occur universally in soils. Their formation in the natural-historical terms is associated with the spread of wildgrowing (ussurian) soybean in the region, and later - with the systematic expansion of cultivated soybean crops [1]. In fact, the Far Eastern natural populations of rhizobia are a significant natural resource that allows selecting the most valuable strains by economically useful properties. Until recently, research of rhizobia in the Far East was limited to the study of Sinorhizobium fredii (Scholla, Elkan, 1984), Bradyrhizobium japonicum (Jordan, 1982) species [2]. Since 1997 various legumes have been grown on the experimental plot of the laboratory for biological research of the All-Russian Scientific Research Institute of Soybean (meadow chernozem soils) in order to identify the species diversity of rhizobia, nodulating soybean. The most active and annual nodule formation was observed in soybean. Nodule formation on the roots in lupine, lablab bean and lentil did not occur for three years of observation. Other legumes (haricot bean, peas, vigna, peavine, chickpeas, beans, peanuts) had unstable nodule formation. According to the technique proposed by the All-Russian Scientific Research Institute of Agricultural Microbiology, in the modification of S.A. Begun, the strains that we assigned to the new species Bradyrhizobium elkanii (Kuykendall et al., 1992) were first isolated in a pure culture from the formed nodules on the roots of vigna ( $V$. radiata and $V$. unguiculata) $(2012)[1,3]$. The isolated strains turned out to be virulent on soybean varieties Garmoniya, MK 100 and Khabarovskaya 4. In total, since 2012, 92 strains of rhizobia Bradyrhizobium elkanii have been isolated in a pure culture from the natural populations of the Russian Far East. These strains were tested by the growth indicators on the agarized mineral-plant medium (MPM) with mannitol and lactose, control medium of MPA (meat-peptone agar), antibiotic resistance.

\section{Видовое разнообразие природных популяций ризобий Российского Дальнего Востока Якименко М.В., Бегун С.А., Сорокина А.И.}

ФГБНУ Всероссийский научно-исследовательский институт сои, Благовещенск, Россия

\begin{abstract}
Аннотация: Спецификой почв Дальнего Востока является наличие в них аборигенных клубеньковых бактерий сои. Детальное изучение морфолого-культуральных, физиологических и хозяйственно-полезных свойств этих микроорганизмов позволило выявить из дальневосточных природных популяций наиболее ценные штаммы B. japonicum, S. fredii, B. elkanii для сохранения их в коллекции.
\end{abstract}

Ключевые слова: соя, зернобобовые, ризобии, виды, итаммы.

Дальневосточный соесеющий регион - единственный в России, где в почвах повсеместно распространены природные популяции клубеньковых бактерий сои. Формирование их в естественно-историческом плане связано с распространением в регионе дикорастущей (уссурийской) сои, а позднее - с систематическим расширением посевов культурной сои [1]. Фактически дальневосточные природные популяции ризобий - это значимый природный ресурс, позволяющий вести отбор наиболее ценных по хозяйственно-полезным свойствам штаммов. Исследования ризобий на Дальнем Востоке до недавнего времени ограничивались изучением видов Sinorhizobium fredii (Scholla, Elkan, 1984), Bradyrhizobium japonicum (Jordan, 1982) [2]. С целью поиска видового разнообразия ризобий, нодулирующих сою, на опытном участке лаборатории биологических исследований Всероссийского научно-исследовательского института сои (луговые чернозёмовидные почвы) с 1997 года выращивались различные зернобобовые культуры. Наиболее активное и ежегодное образование клубеньков отмечено у сои. У люпина, лобии и чечевицы образование клубеньков на корнях не происходило на протяжении трёх лет наблюдений. У остальных зернобобовых культур (фасоль, горох, вигна, чина, нут, бобы, горох, арахис) образование клубеньков было неустойчивым. Из образовавшихся клубеньков на корнях вигны (V. radiata и V. unguiculata) (2012 г.), впервые были выделены в чистую культуру штаммы, отнесенные нами к новому виду Bradyrhizobium elkanii (Kuykendall et al., 1992), по методике предложенной ВНИИСХМ, в модификации С.А. Бегуна [1, 3]. Выделенные штаммы оказались вирулентны на сое сортов Гармония, МК 100 и Хабаровская 4. Всего за период с 2012 г. из природных популяций Российского Дальнего Востока выделено в чистую культуру 92 штамма ризобий Bradyrhizobium elkanii. Эти штаммы проверены по показателям роста на агаризованной среде МРС с маннитом и лактозой, контрольной среде МПА, устойчивости к антибиотикам.

1. Бегун С. А. Способы, приемы изучения и отбора эффективных штаммов клубеньковых бактерий сои. Методы аналитической селекции: методрекомендации. - Благовещенск: ПКИ «Зея», 2005. - 70c.

2. Rhizobiaceae. Молекулярная биология бактерий, взаимодействующих с растениями / пер. с англ. под ред. И. А. Тихоновича и Н. А. Проворова. - Санкт-Петербург: ООО «ИПК «Бионт», 2002. - 567 с.

3. Kuykendall L. D., RoyM. A., O’Neill J. J., Devine T. E. Fatty acids, antibiotic resistance, and deoxyribonucleic acid homology groups of Bradyrhizobiurn japonicum // Int. J. Syst. Bacteriologi. -1988. - Vol.38. - P. 358 - 361. 